\title{
ACQUITTALS OR CONVICTIONS AS BARS TO PROSECUTIONS FOR PERJURY
}

The procession of cases involving the entangled pleas of former jeopardy and res judicata as applied to the criminal law suggests that courts have failed to grasp the distinction between the two pleas. The Supreme Court, however, will soon have the opportunity to lift the veil of confusion, since $U$. S. v. Williams, ${ }^{1}$ now pending before that Court, ${ }^{2}$ confronts it with the necessity of exploring the spheres in which former jeopardy and res judicata are applicable.

In the Williams case, defendant Williams, having been tried and convicted for violating the Civil Rights Act, was indicted for perjury because of his allegedly false testimony at the trial. Williams' co-defendants, charged with aiding and abetting him in violating the Civil Rights Act, were acquitted of that charge, but they too, were indicted for perjury because of the testimony given by them at the trial. The various defendants entered pleas of former jeopardy and res judicata, upon which the District Court of Florida dismissed all the indictments for perjury, and the Government appealed to the Supreme Court.

Undoubtedly the doctrines of res judicata and former jeopardy arise from the same policy that a man should not be twice subjected to jeopardy for the same cause, and that litigation must come to an end. ${ }^{3}$

Former jeopardy, which is expressly prohibited by the constitutions of most of the states as well as that of the United States, ${ }^{4}$ comes into play when there is an effort to

193 F. Supp. 922 (1950).

219 L.W. 3204 (1951) (argued before Supreme Court).

- Miller, Criminal Law, \& 186 (1934); Gehlbach, Res Judicata and Conspiracy, 65 J. Crim. Law 58 (1948).

- A.L.I. Administration of the Criminal Law, 86, Comment A (1936). All but five states-Connecticut, Maryland, Massachusetts, North Carolina and Vermont-have a constltutional provision against a second trfal for the same offense. The Coustltutions of thirty-five states and the United States provide that an individual shall not be twice subjected to "jeopardy"; elght provide that after an acquittal a person shali not be tried again for the same offense. Nothing is revsaled in any constitution as to what constitutes "jeopardy" or what is the "same offense". 
prosecute a defendant for an offense of which he has already been acquitted or convicted. Thus, as applied to the criminal law, it is similar to the doctrines of merger and bar which apply in civil actions to preclude a second suit on the same cause of action. ${ }^{5}$

The doctrine of criminal res judicata-at least, as used here-signifies that an issue once litigated in a criminal proceeding can not be relitigated between the state and the same defendant. It makes no difference that the offense prosecuted in the second proceeding differs from that of the former action, so long as the issue to be determined in the second prosecution has been adjudicated in the first. Res judicata is the analogue of what in civil actions is termed collateral estoppel. ${ }^{\circ}$ However, unlike double jeopardy, res judicata receives no explicit constitutional sanction unless; as seems rather doubtful, it may be deemed to have been cauglit up in the ample folds of due process.

An illustration of the distinction between former jeopardy and res judicata is afforded in the not infrequent situation, especially in the Federal Courts, where a crime is charged, and, either in another indictment or a second count of the same indictment, the defendant is charged with having conspired with others to commit the substantive offeuse. It now seems well settled that acquittal of the conspiracy charged would not constitute former jeopardy as to the prosecution for the crime itself; and vice versa. The offenses are neither the same in fact nor in law; either can exist without the other. If, instead of an acquittal on one charge there is a conviction on both, the absence of former jeopardy permits consecutive sentences to be imposed.

The plea of.res judicata would be applicable however, if the charges are separately tried, for in such an instance, the first adjudication may be legally conclusive as to some point involved in the second prosecution. In Sealfon $v$. U. S., A was acquitted of conspiring with B to commit a

- Of. Restatement, Judgments 8847,48 (1942).

- Of. Restatement, Judgments 88 68-72 (1942); Scott, Oollateral Estoppel by Judgment, 56 Harv. L. Rev. 1 (1942).

322 U.'S. 575 (1948). 
substantive offense, because the evidence failed to show an agreement between the two persons. In a subsequent trial of $A$ for aiding and abetting $B$ in committing the crime, the Government was held by the Supreme Court to be precluded by res judicata from reliance on the same evidence to show a relationship between $A$ and $B$.

Further examples of the operation of both former jeopardy and res judicata will be offered in analyzing each doctrine and in determining whether either affects the situation involved in U.S. v. Williams.

\section{Former Jeopardy}

Under former jeopardy. "No person shall be subject for the same offense to be twice put in jeopardy of life or limb."8 This raises the vexing problem: When are two offenses "the same"?

Various tests have been laid down by the courts to answer this question. An old English case undertook one of the earliest efforts to answer this question in its test that: "Unless the first indictment were such as the prisoner might have been convicted upon proof of the facts contained in the second indictment, an acquittal on the first indictment can be no bar to the second."

Other courts restated this rule affirmatively to say that if the evidence necessary to support the second indictment

D. S. Const. Amendment 7 .

- Vandercomb's Case, 2 Leach C. C. 708, 720 (1796). The test was however, not tollowed in two later cases. In Rex v. Sheen, 2 C \& $P 634$ (1827), it was held that an acquittal of murder of 8 bastard child known under one name is a bar to a.prosecutiou for murder of a bastard child known under another name where the jury finds that only one child was killed and it was known under both names. In Rex $\nabla$. Clark, 1 B. \& B. 473 (1820), an acquittal of giving poison by forcing child to "swallow" poison was a bar to a prosecution for administering poison by forcing the child to "take into the throat" the poison by which the child died. 
would support a conviction under the first indictment, the two offenses are the same. ${ }^{10}$

Suppose that under a murder indictment the criminal procedure of the applicable jurisdiction does not permit a conviction of assault and battery. In such instances, under the traditional rule that has been stated, an acquittal of murder would not seem to constitute former jeopardy for a second prosecution charging assault and battery. The evidence that would sustain a conviction of assault and battery would not have sustained any conviction permissible under the first indictment. Thus the defendant was never before in jeopardy for the offense of assault and battery.

Such an analysis, however correct theoretically, would probably be shrugged off by the court. The constant assertion of the commentators to the effect that acquittal or conviction of a greater offense bars a prosecution for any lesser offense, ${ }^{11}$ has not contained the limitation that under applicable procedural rules the defendant could have been convicted of a lesser offense under the indictment for the greater. Accordingly, in our hypothetical case of an acquittal for murder, few courts would permit a subsequent indictment for assault and battery.

The commentators' statements may be correct in instances of a conviction for a greater offense followed by a prosecution for a lesser, included offense; under the doctrine of merger, the conviction of the greater would swallow up all lesser crimes. ${ }^{12}$ However, in cases of an acquittal of a

10 People 7. Defoor, 100 Cal. 150 (1893). The first information charged assault with intent to murder, based upon the defendant hitting the victim with a bottle. This action resulted in a confiction of assault. This was held to bar an action for mayhem, founded on the fact that defendant bit the finger of the victim which later had to be amputated, on the ground that it occurred during the same assanit. In State v. Price, 127 Iowa 301 (1905), the court in holding an acquittal of statutory rape a bar to a subsequent prosecution for incest (though another act of intercourse was alleged) the court said: "It is conceded that the same testimony would have supported either charge." See also Moore v. State, 59 Miss. 25 (1881).

II See, e.g., Miller, Oriminal Laio, 50 (1934).

12 Com. v. Roby, 12 Plck. (Mass.) 496 (1832). But, as the rule was formeris stated, merger applled onls to an offense of less degree. Thus a felony would swallow up a misdemeanor but not another felony; nor would a misdemeanor swallow up another misdemeanor. 
greater offense followed by prosecution for a lesser, merger would not apply, and barring a second prosecution would involve some disregard of the traditional "same evidence rule" for applying former jeopardy.

Not only disregard but also occasional reformulation has been the fate of the oft-stated "same evidence rule." One court has suggested: "Another rule sometimes adopted is that the conviction or acquittal on one indictment will be a bar to another prosecution growing out of the same transaction." However, the Court retreated after this approach to a doctrine that there should be only one offense punishable on the basis of a single transaction; it added that "this also must be taken as a true rule in a general sense. A single act or transaction may be an offense against two statutes or against the law of two different jurisdictions, in which case one prosecution will not bar the other."13

The proliferation of statutory provisions creating new criminal offenses, State and Federal, makes the latter remark especially significant. For instance, a bootlegger prosecuted and convicted by State authorities is still subject to prosecution in the Federal Courts for the same offense; and if convicted he may be sentenced for a term to begin after his State sentence expires. Or frequently, by what amounts to a single act, the defendant may become subject to prosecution for violation of several different statutory provisions. ${ }^{14}$ Unless one includes in its definitions all the elements of the others, he may find himself serving consecutive sentences for the violations. ${ }^{15}$

Another court, groping for a broader test of former jeopardy, has stated: "When the facts constitute but one offense, though it may be susceptible of division into parts, as in larceny for stealing several articles of property at the same time, belonging to the same person, a prosecution to final judgment for stealing a part of the articles will be a bar to a subsequent prosecution for stealing any other part of the articles, stolen by the same act."16

${ }^{13}$ State v. Stewart, 11 Ore. 238, 4 Pac. 128 (1883).

1s See, e.g., Albrecht v. U. S., 273 U. S. 1 (1927).

is Cf., Ekberg v. U. S., 167 F. 2d 380 (1st Cir., 1948).

${ }_{18}$ See State $\nabla$. Elder, 65 Ind. 282, 285 (1879). 
While some courts have strained to broaden the operation of former jeopardy, others have narrowed it still further; they have erected an exception that "when after the first prosecution a new fact supervenes, for which the defendant is responsible, which changes the character of the offense, and together with the facts existing at the time constitute(s) a new and distinct crime, an acquittal or conviction of the first offense is not a bar to an indictment for the other distinct crime."17 Accordingly, if after a prosecution for assault and battery with intent to commit murder, the victim should die, a prosecution for murder is not subject to the plea of former jeopardy. ${ }^{18}$

Does not this exception dispose of the argument that former jeopardy operates in the situation of the Williams case? At the time of the indictment for violation of the Civil Rights Act the alleged perjury had not occurred. Indeed, it was the trial on that very indictment that gave rise to the occasion for the acts of perjury. The falseswearing of the defendants was certainly as much of an intervening event brought about by the defendant as the death of the victim would be after prosecution for assault and battery. Moreover, no one can suggest that the prosecutor, in contravention of the policy underlying the doctrine of former jeopardy, was seeking to vex the defendant by "splitting a cause of action" and bringing in two indictments when he could have brought in only one.

Regardless of the "intervening fact" view, it is hard to see how the perjury with which defendants are now charged could be the same offense as the crime for which they were formerly tried. Perjury consists in wilfully giving false testimony about a material unatter before a competent tribunal. ${ }^{19}$ The first prosecution, on the other hand, was for acts of violence and under color of law whereby complaining witnesses had been deprived of the rights and privileges secured by the laws of the United States. ${ }^{20}$ The transactions were quite different in time and place; the

${ }^{17}$ See State v. Littlefield, $70 \mathrm{Me.} \mathrm{452,} 456$ (1880).

18 Com. v. Ramunno, 219 Pa. 204, 68 Atl. 184 (1907).

2818 U.S.C.A. \$1621.

$\infty 18$ U.S.C.A. 8242. 
criminal intent to be proved at the two trials was different; and the physical acts constituting the second offense were of a different category than those initially prosecuted. The first prosecution was in no way designed to prosecute the type of criminality constituting perjury.

Perhaps in some instances the evidence necessary to sustain an indictment for perjury would have sustained a conviction for the substantive offense prosecuted at the first trial. This might be true if the alleged perjury consisted merely of a general statement by defendant at his first trial that he was not guilty of the offense charged. If, however, his testimony related to only one of the several issues in the case, and, a fortiori, if it related to a collateral matter like the defendant's good character, proof of the falsity of the defendant's statement would not necessarily prove guilt of the offense first charged.21

The incredulity with which the courts have greeted the assertion that former jeopardy is involved when a defendant is prosecuted for perjury committed at his previous trial for some other offense, has been expressed in several decisions. One court remarked: "By no stretch of the imagination can an assault with intent to murder committed on June 13, 1912 be held to be the same offense, or anything akin to it, as perjury committed on September 17, 1912, even though the perjury is committed on the trial of the assault to murder case." 22 Any opposite conclusion would scarcely be in keeping with those decisions which have limited former jeopardy so as to permit more than one prosecution for a single transaction in which the defendant ran afoul of several State and Federal statutory provisions.

${ }^{21}$ Chitwood r. U.S., 178 Fed. 2d 442 (8th Cir. 1910). At page 443 the Court said: "But if the particular testimony alleged to be false is as general and broad as the charge of the crime-in other words, a denial of guilt - a trial for perjury is virtually a second trial of the prior case." of. Kuskulis v. U. S., 37 F. 2d 241. (10th Cir. 1929).

22 Miles v. State, 165 S.W. 567 (1914). The accused was indicted for assault with intent to murder, and on the trial of that offense wilfully and falsely testified that he did not shoot or assault the victim; his acquittal on the charge of the assault did not constitute a former jeopardy so as to preclude his subsequent trial and conviction for perjury committed in the assault case. 
The argument that to permit the plea of former jeopardy would immunize a perjurer from punishment has influenced the courts. "It would make no difference whether convicted or acquitted, he (the defendant) would be immune from perjury in either event."23

In the principal case the Court dismissed the indictment of both Williams, who had originally been convicted, and his co-defendants, who had been acquitted. The dismissal was based on Ehrlich v. U. S.24 There the gravamen of the charge was that the defendant had received excessive prices for meat, though billed at the legal rate. The defendant denied such receipt and was acquitted. He was later charged with perjury, his denial at the first trial being the basis for the charge. The Court held that the acquittal barred a subsequent prosecution for perjury with reference to defendant's testimony about the act which constituted the basis for the first prosecution. The jury's verdict was felt necessarily to determine that issue of perjury. The court said: ". . . it appears to be well settled that where the fact testified to and as to which the perjury is charged was the act constituting the basis of the crime charged,-and this fact was necessarily determinative of the issue,-an acquittal of the first offense bars a prosecution for perjury."25 The Ehrlich opinion cited and seemed to follow U. S. v. Butler, ${ }^{26}$ where the court held that an acquittal for selling liquor without payment of tax required by law was a conclusive adjudication in defendant's favor upon his subsequent trial for perjury, and that the government could not show that the defendant, having sworn under oath that he did not so sell, swore falsely.

However, a.thorough analysis of the Ehrlich and Butler cases revcals that these decisions seem to be explicable in terms of res judicata rather than former jeopardy. ${ }^{27}$ The Butler case explicitly relates that there is no former jeop-

23 See Murff v. State, 76 Tex. Cr. 5, 12, 172 S. W. 238, 241 (1914).

24 145 F. 2d 693 (5th Cir. 1944).

- Id. at page 693.

2038 Fed. 498 (F. D. Mich. 1889).

In Incidentally, the annotators of 18 U.S.C.A. $\$ 1621$ (1950), seem to be guilty of confusion in classifying $U$. S. V. Ehrlich-and some other cases-under former jeopardy rather than under res judicata. 
ardy, but holds that the issue of the defendant's veracity was (indirectly) passed upon at the first trial, and can not be rehitigated. This being so, the Ehrlich case might be authority for dismissing the indictment as to Williams' co-defendants, who had initially been acquitted. But it would not be applicable for dismissing the indictment as to Williams, who, having been initially convicted, could scarcely claim any benefits from the doctrine of res judicata.

\section{Res Judicata}

The doctrine of res judicata signifies that:

"When the second suit is upon a different cause of action, but between the' same parties, as the first, the judgment in the former action operates as an estoppel in the latter as to every point and question which was actually litigated and determined in the first action, but it is not conclusive as to other matters which might have been, but were not, litigated or decided."28

In short, res judicata precludes relitigation of any issue upon which a jury has once passed.28 Consequently, to invoke res judicata requires that the court passing on the plea must possess a knowledge of what was decided at the original trial. For instance, suppose there were two elements, $A$ and $B$, in the prosecution's case at the initial prosecution, and the defendant admitted neither. If there was an acquittal, how could a subsequent court know-in the absence of a special verdict-whether the acquittal had resulted because the jury felt that the State had proved $A$ but failed to prove $B$, or proved $B$ but failed to prove $A$, or proved neither A nor B? Since the former verdict is conclusive only as to facts directly and distinctly put in issue, and the finding of which is necessary to uphold the judgment, it can be argued that no res judicata resulted from the acquittal. For instance, if the defendant should claim that the acquittal was determinative of the nonexistence of $A$, the State can argue that finding the non-

so Stone, Res Judicata in Criminal Cases, 27 Tex. L. Rev. 231 (1948). The doctrine seems to have been first formulated in the famous Duchess of Kingston case, 20 St. Tr. 355 (1779).

20 People v. Rogers, 102 Misc. 437, 170 N. Y. Supp. 86 (1918). 
existence of A was not necessary to the prior judgment, for the acquittal is perfectly consistent with the hypothesis, $A$, but not $B .^{30}$ Of course, this argument disregards the irreibuttable, but irrelevant, proposition that "for all that can ever be known, the jury's estimate of the facts" as to A "caused it to find a verdict of not guilty."

Since the same reasoning can be advanced to dispute the suggestion that the prior acquittal is conclusive of the nonexistence of $B$, the acquittal creates res judicata neither as to A nor B. Of course, it would settle that both A and B can not be true in a subsequent prosecution of the defendant, but if both $A$ and $B$ are involved in the subsequent prosecution, the defendant would in most instances have available the plea of former jeopardy.

Where, however, a defendant is able to show, by the same record that his acquittal in the first prosecution rested upon a defense which would determine the issues in the second trial, the state would be estopped from litigating the issue. ${ }^{32}$ If, for example, the defendant were to invoke an affirmative defense, like alibi, or self-defense, and the record were to show that the reason for his acquittal was that the jury believed his testimony, a subsequent prosecution involving the same acts and defended by the same plea, would be precluded on the ground that the defense had once been placed in issue and was adjudicated.

If the defendant is claiming, as in the Williams case, that his acquittal is res judicata in his favor when prosecuted for perjury allegedly committed in the course of the first litigation, he must show at least that the acquittal did logically imply that the jury believed his testimony. Thus, if the perjured testimony related to an issue that was material but not essential to the determination of the trial, defendant could scarcely claim res judicata. For instance, a false oath as to character would be material, since "material" means "legally capable of being proved in the cause" and refers to "testimony that will legally evidence the prop-

× Ibid, Of. Kuskulis v. D. S., 37 F. $2 d 241$ (10th Cir. 1929).

a Bee Kuskulls v. U. S., 37 F. 2d 241, 243 (10th Cir. 1929) (dissent. ing oplinion).

- Harris v. State, 193 Ga. 109, 17 S. E. 2 d 573 (1941). 
osition to be proved."ss However, it would not be on ar. ultimate issue in the case, so that acquittal would be perfectly consistent with the thesis that the jury believed defendant to be lying about his character but thought that, despite his bad character, he had not committeed the particular offense charged. ${ }^{34}$

The cases conflict as to whether the defendant's acquittal upon a criminal charge bars a subsequent prosecution for perjury with reference to defendant's testimony about the act constituting the basis for such a charge, as in the principal case. But both state and federal courts seem to agree that one's acquittal upon a criminal prosecution is not a bar to subsequent prosecution for perjury committed at the former trial, where his testimony related merely to collateral matters and its falsity was not necessarily inconsistent with his innocence of the former crime. ${ }^{35}$

In our principal case, where the offense charged was a violation of the Civil Rights Act, the indictment would require proof of two elements: that defendant had committed the assault and battery and that he had done so under color of office. If defendant's allegedly perjured testimony related to only one of these, for example the assault, would not an acquittal be consistent with the proposition that the jury thought he had lied about committing the assault but felt that, though he had brutally assailed the victim, he had not done so under color of office? Thus, no res judicata would result. On the other hand, a conviction of defendant would clearly mean that the jury, which decided every issue against the defendant, determined that he had committed the assault, and thus impliedly determined that he had lied in saying he had not committed the assault.

The difficult case would be that in which the defendant had testified as to every element of the crime and is being indicted for his testimony after the acquittal, with each statement being the basis for a separate count. The foregoing analysis indicates that to convict on one of these counts would not be to relitigate issues determined by the

3 See U. S. v. SIutzsky, 79 F. 2d 504, 506 (3rd Cir. 1935).

s Of. Kuskulis v. U. S., 37 F. 2d 241 (10th Cir. 1929).

* State v. Reynolds, 100 P. $2 d 593$ (1940). 
acquittal. But to convict on all, would be to undermine that prior acquittal, since the jury necessarily concluded that at least one element of the crime did not exist. Therefore, the State cannot dispute that the defendant was telling the truth in at least one of his statements denying the various elements of the crime.

In this situation former jeopardy; embodying a policy against splitting a cause of action, would presumably preclude consecutive sentences if defendant were convicted on all the connts embodying his different statements made at the first trial. ${ }^{36}$ Therefore the sentence imposed could not rightfully exceed that which would be permissible on any single count. But, since a conviction on one of the counts, or, indeed, on all the counts except one, would be valid, it would seem that the sentence should be referred to those counts for perjury not barred by the defense of res judicata. Thus, the conviction would stand.

So far the discussion has proceeded under the implied premise that criminal res judicata is a doctrine universally accepted. However, some courts seem to refuse it any recognition. One court, where the defendant was acquitted of the offense charged at a previous prosecution, in the subsequent trial for perjury asserted:

"In criminal prosecutions each fact relevant and admissible in each separate prosecution may be proved by testimony produced before the jury in that trial, and it is immaterial what credence another jury in another prosecution for a different and distinct crime may have given the same or other testimony then produced in respect to the same fact; because public policy demands that when the state charges a citizen with the commission of a distinct crime, that charge shall be considered independently of any past transgressions." ${ }^{37}$

Whether the Federal courts would in any case accept the doctrine of criminal res judicata was at one time somewhat confused. Most of the confusion arose from a dictum of Justice Holmes in Dunn v. U. S., ${ }^{38}$ which involved the validity of inconsistent verdicts rendered on various similar

* Cf. Ekberg v. U. S., 167 F. 2d 380 (1st Cir., 1948).

st See State V. Vandemark, 77 Conn. 201, 203, 58 Atl. 715, 716 (1904).

$\infty 284$ U. S. 390 (1932). 
counts. Justice Holmes, in sanctioning the inconsistency, remarked: "This is no more than would have occurred if two separate prosecutions had been involved for the determination of one charge would not constitute res judicata as to the other." 39 Why it would not constitute res judicata was never too clear, unless it was assumed that res judicata was not applicable in federal prosecutions.

Subsequently, in the Sealfo $n^{40}$ case, the court gave at least a partial welcome to the doctrine of res judicata, and held that an acquittal precluded relitigation of an issue necessarily determined by the acquittal. This holding focuses on protection of defendants against vexatious prosecutions.

In opposition, it can be argued that society's interest in punishing criminals should not be prejudiced in a later case by the ineptitude with which a former prosecution was handled. Also emphasis can be placed on the state's inability to appeal from errors of law committed at a trial, even though those errors may have induced the jury's adverse determination. Should the state be further penalized by being bound by that determination when it brings a later prosecution for an entirely different crime?

The argument that res judicata should not stem from an acquittal gains added force when the second prosecution is for perjury committed at the first trial; perhaps the acquittal was induced by that very perjury. If res judicata is allowed to result from the former acquittal, may not the perjurer be lifting himself by his own boot straps? Accordingly one Court suggested: "The efficient as well as the correct administration of justice demands that the defendant in a prosecution for perjury should not be allowed to plea in bar of the prosecution the judgment of acquittal in the case in which the alleged false testimony was given." 41 Perhaps the special circumstances in this situation provide a basis for avoiding an operation of the Sealfon rule. The prosecution would probably be required, however, in the

\footnotetext{
so Id., at page 393. As to inconsistent verdicts, see Bickel, Jiudge and Jury-Inconsistcnt Verdicts in the Federal Court, 63 Harv. L. Rev. 649 (1950).

so Supra, note 7.

¿See Teague v. Comm., 172 Ky. 665, 670, 189 S. W. 908, 910 (1916).
} 
proper exercise of judicial discretion, to introduce some evidence not presented at the former trial.42

The contention has also been made that to allow a subsequent prosecution for perjury where the indictment for perjury is based upon the testimony of the defendant at the former trial in which he denied his guilt, and where the verdict rendered was in favor of the defendant, would be to permit prosecution to continue ad infinitum-and thus to defeat the very purpose of the doctrines of res judicata and former jeopardy. ${ }^{48}$

For the purpose of exploration let us suppose a hypothetical case. $X$, having been duly indicted, was tried and acquitted of assault and battery. A subsequent prosecution is instigatod wherein $X$ is charged with perjury, the basis of which is his denial at the former trial of acts constituting assault and battery. At this perjury trial, $X$ offers pleas of former jeopardy and res judicata, which are rejected by the court. During this perjury trial $X$ again takes the stand, gives testimony substantially the same as before, and is acquitted. $X$ is again indicted for perjury, the basis of this indictment being his denial of the assault and battery, and the only new feature being that the perjury now indicted took place at the second rather than at the first trial.

The acquittal of the defendant in the first trial (for assault and battery) was held not to bax a subsequent trial for perjury (trial number 2) although by implication. it attested the veracity of the defendant's testimony. How then could the acquittal of perjury, despite its explicit finding as to the defendant's veracity be any more of a bar to a later perjury trial than was the acquittal of assault?

Perhaps the distinction lies in the very fact that in one instance the jury did make the explicit finding. As one court suggested: "In the perjury trial, the question for the first time is squarely before the jury as to the truth of the defendant's testimony." 44 Moreover, veracity is the ultimate issue in perjury.

af., Allen v. U. S., 194 Fed. 664 (4th Cir. 1912).

- See State V. Archuleta, 217 Pac. 619 (N. M. 1913). (1988).

$\omega$ Id., at p. 622. Of., Com. 7. Spirey, 243 Ky. 483, 48 s. W. 2d 1076 
It can also be suggested that irrespective of res judicata, former jeopardy would apply to preclude the second perjury prosecution. There is a recognizable difference between assault and battery and perjury-between the offenses tried at trials one and two. On the other hand, trials two and three-both for perjury-involved offenses with substantially identical elements. Indeed, the only distinction would be as to the time of the respective utterances; and the statements correspond to such a dgree that to prove the perjury charged at trial three would necessarily be to prove the perjury tried at trial two. Accordingly, even though the giving of testimony at trial two constituted an "intervening fact", it appears probable that courts would hold that under the "same evidence", or any other, rule the second prosecution was barred by former jeopardy.

At all events, the effort to supply a reductio ad absurdum encounters the practical obstacle that, regardless of the theory adopted, no court will allow a second trial for perjury after a defendant has first been acquitted of a crime and then acquitted of perjury allegedly committed at his trial for the substantive offense. ${ }^{45}$

Most of the preceding remarks consider whether an acquittal should create res judicata. But what about the significance of the conviction of the principal defendant, Williams, who is now being prosecuted for his alleged, and rather fruitless, perjury at the first trial? Unlike the cases of a prior acquittal, there is no doubt as to the issues on which the jury based their decision. To convict, they were obligated to decide every issue in favor of the prosecution.

If double jeopardy could be invoked, the prior conviction, like a prior acquittal, would create immunity for the defendant. But under res judicata the conviction at the first trial, instead of granting immunity, would tend to produce an automatic conviction. Since the conviction signified that the jury decided every issue against the defendant, it must have concluded that he was lying about any issue in the

w See State V. Archuleta, 217 P. 619, 622 (N. M. 1937). "If the defendant is acquitted of perjury committed in the former trial for murder, wherein he had been likewise acquitted, the judgment of acquittal would be a bar against any further prosecution for perjury." 
case as to which he testified. If criminal res judicata operates against the defendant, his testimony at the first trial cannot now be proved to be true. His statement, having related to an issue at that trial, was clearly material. The only thing left for the State to prove would be that the testimony was made with knowledge of its falsity rather than through an innocent mistake. Yet how difficult would it be to convince a jury that a defendant who gave untrue testimony as a witness in his own behalf was doing so intentionally?

If the State could thus avail itself of criminal res judicata, to convict of perjury a previously-convicted defendant who had testified in his own behalf would be nothing more than a formahty. Indeed, it would be almost as automatic as the conviction obtained in Commonwealth v. Evans. ${ }^{40}$ In that case the defendant had been convicted of assault and battery. When subsequently his victim died, defendant was indicted for murder. He sought to introduce evidence sustaining a plea of self-defense, on which he had vainly rehed in the first case; but it was excluded on grounds of res judicata. Consequently the State had only to prove that the victim died of the wounds inflicted by the defendant in order to sustain the indictment.

But will res judicata be applied against the defendant in any criminal case? In support of its applicability it can be argued in those jurisdictions permitting a defendant to claim res judicata that such a result is implicit in the doctrine of mutuahity of estoppel-that "no person can claim the benefit of a judgment as an estoppel unless he would have been prejudiced by a contrary judgment or decision."17 The Supreme Court has spoken of res judicata as being "as applicable to the decisions of criminal courts as to those of civil jurisdiction," 48 and has speken with approval of Commonwealth v. Evans's utilization of the principle of "the finality of a previous adjudication as to the matters determined by it," "the criminal and the civil law agreeing."10

- 101 Mass. 25 (1869). See 27 Tex. L. Rev. 231, 239 (1948).

" Quoted in U. S. จ. Carlisi, 32 F. Supp. 479, 183 (E.D.N.Y. 1940).

4 See Frank v. Mangum, 237 U.S. 309, 334 (1912).

4 See U.S. จ. Oppenheimer, 242 U.S. 85, 87 (1916). Of. 27 Tex. L. Rev. 231 (1948). 
Under these statements of the Supreme Court there seems no reason to believe that mutuality of estoppel, a normal rule of res judicata, would not be applied and that a defendant could not be bound by a conviction for purposes of subsequent prosecution. However, a Circuit Court has confused matters by stating: "Nor can tliere by any requirement of mutuality witl respect to a criminal judgment's conclusiveness." 50

Mutuality of estoppel would then, in general, support the application of criminal res judicata. against the defendant. If, however, in the situation presented by the principal case, an exception is created to the normal rule that acquittal produces res judicata in behalf of the defendant, mutuality of estoppel would proclaim that conversely a conviction should not benefit the prosecution in the trial for perjured testimony at the earlier trial.

The same Circuit Court whicl stated there is no requirement of mutuality as to a criminal judgment's conclusiveness, asserted: "An accused is constitutionally entitled to a trial de novo of the facts alleged and offered in support of each offense charged against him, and to a jury's independent finding with respect thereto."51 This "constitutional right" seems to a great extent, to be founded upon sympathy for defendants and a feeling that in every trial a defendant should be entitled to full reliance on his presumption of innocence independent of the trammels of res judicata.

Perhaps practical considerations enter into the reluctance to apply res judicata against a defendant. If, instead of two trials for two offenses, the charges had been combined as counts of the same indictment, the jury in the exercise of its mercy and discretion, might have acquitted on one count and convicted on the other. Even if inconsistent, the verdict on the two counts would stand. It could be argued, that the defendant should be allowed as good an opportunity as he might have received if the counts had been combined. Since, however, the prosecution, in separating the two charges into different indictments, has run the risk of res

so U.S. v. De Angelo, 138 F. 2a 466 (3ra Cir. 1943).

aI Id. at p. 469 . 
judicata from the first charge operating against the State, why is it unjust to give the State the benefit of the conviction?

Another consideration as to the application of res judicata against the defendant is that to do so might induce prosecutors to improve their won-loss averages by using a prior conviction as a basis for a "push-over" second conviction. It has already been suggested that conviction of an offense might lead to an almost automatic subsequent conviction of perjury by a defendant who had testified in his own behalf. Might not a prosecutor be tempted by the easy chance to better his percentage of convictions obtained?

One technical evidentiary consideration strongly suggests that, independent of whether, in general, res judicata operates against a criminal defendant, it should not do so where the second trial is for perjury. Perjury and treason are still subject to the "two witness rule", which measures the evidence by quantity as well as quality, and requires that the perjury charge be corroborated by two witnesses. ${ }^{52}$ If a prior conviction binds the defendant under res judicata as to the most significant issues under the indictment against him, he is deprived of any opportunity to benefit from the special requirements for a perjury conviction. Consequent$\mathrm{ly}$, "the rule that the determination of an issue of fact in a criminal case is conclusive in a subsequent criminal proceeding against the same defendant does not apply to a prosecution for perjury * * * since in criminal prosecutions generally a conviction may be had upon the evidence of a single witness, while a conviction of perjury cannot be had upon the uncorroborated testimony of but one witness."

Moreover, it probably should make no difference whether or not the State presented two or more witnesses in support of the charge at the trial where the defendant allegedly perjured himself. After all, presumably the case was submitted to the jury under normal "reasonable doubt" instructions, nothing being said about the number of witnesses. The jury may have found only one witness credible, but found that he was so credible as to prove the State's case

Weller v. U.S., 323 U.S. 606 (1945).

atate V. Sargood, 80 Vt. 415, 68 Atl. 49 (1907). 
beyond a reasonable doubt. In view of this possibility, the State, it could be argued, should not be allowed to claim the benefits of res judicata arising from the original conviction. Even if the "two witness" rule is an anachronism, so long as it remains law defendants should not be barred by res judicata from utilizing it in defending against the perjury indictment.

One further possibility remains by which the prosecution could claim assistance under the doctrine of res judicata. The prosecutor, after the conviction of a defendant who had testified in his own behalf, might move to have the defendant cited for criminal contempt, the contempt being the alleged perjury. Defendant's false swearing would seem to be punishable for contempt since its purpose was to obstruct the administration of justice. ${ }^{54}$ Presumably the contempt citation, like false swearing in Bankruptcy proceedings, ${ }^{55}$ would not be subject to perjury's technical requirement of corroboration by two witnesses. The falsity of the defendant's testimony would have been conclusively adjudicated against him by the jury verdict, so that no hearing would be required on that point. The intent to obstruct by falsehood would be a compelled inference from the circumstances, once the testimony's lack of truth was taken to be conclusively established. Attempts to obtain such a contempt citation would seem improbable, but heated litigation might generate a desire in the prosecutor to "throw the book" at the defendant. Apparently the contempt citation would not, under double jeopardy, bar a subsequent indictment for perjury.

If the contempt citation for perjury obstructing justice followed an acquittal, its'validity would presumably hinge on the same considerations of former jeopardy and res judicata that have already been set forth. Perhaps an effort to use the sanctions of criminal contempt because of testimony offered at a trial might in some instances be viewed by a judge as an unwarranted effort of the prosecutor to deprive a defendant of his right to a jury on a perjury charge.

os Cf., U.S. v. Brown, 116 F. 2d 455 (7th Cir. 1940). But see in re Michael, 326 U.S. 224 (1945).

\&s Schonfeld v. U.S., 277 Fed. 934 (2nd Cir. 1921), ccrt. denied, 258 U.S. 623 (1922). 


\section{Conclusion}

Former jeopardy and res judicata both spring from the principle that litigation must be terminable, and that one should not be compelled to prove the same thing an illimitable number of times.

The principal case here fails to conform to the standards of the various tests apphicable to determine the identity of the offenses. As has been suggested, surely one would not concede that perjury and a violation of the Civil Rights Act by acts of violence were identical either in law or in fact; accordingly a plea of former jeopardy should not be recognized in the Williams case as precluding the subsequent action for perjury.

Further while public policy on the one hand demands the termination of all litigation, and thus gives rise to the doctrine of res judicata, on the other hand there is no public policy in favor of shielding perjury with artificial refinements and narrow technicalities. ${ }^{86}$ It would be an inexcusable monstrosity to allow one to offer perjured testimony in the courts to insure an acquittal, and then to set up that very acquittal as $a$ bar for the indictment of the acts of perjury. This would be in effect permitting a principle whose very creation was to effect justice to be used to defeat that purpose. Public policy does not guarantee immunity to criminals.

Whether a conviction should not only not be a defense to the defendant, but should be available as a weapon against him is debatable. To apply res judicata against the defendant may in some instances subject him to drastic consequences derived from a case that he did not feel to be of exceptional importance, and litigated with comparative indifference. Moreover, even if criminal res judicata normally should operate against a defendant, it seems that a conviction followed by a prosecution for defendant's alleged perjury at the previous trial may present an exception to the general rule.

A defendant's plight is indeed unenviable. If he stays off the stand, his silence may influence the jury against him;

* Cf., Jay v. State, 15 Ala. App. 255, 73 So. 137 (1916). 
and in some jurisdictions it may even be commented on by the prosecutor. ${ }^{57}$ Yet if he goes on the stand, he can be mercilessly grilled about his past indiscretions or misdeeds, about any prison record, and in addition, he must consider the possibility that his victory may be made hollow, or his defeat even more calamitous, should the trial be followed up by prosecution for perjury because of that to which he testified. But though the defendant does find himself in this precarious position, our courts should not sanction an application of res judicata or former jeopardy that would defeat administration of justice or preclude society from bringing to bay one who through his perjured testimony has endeavored to obstruct justice.

JOHN A. DWYER.

or Adamson v. California, 332 U.S. 46 (1947). 